\title{
Rapamycin enhances the antiproliferative effect of transforming growth factor- $\beta$ on MCF-7 human breast cancer cells
}

\author{
GUOPING WANG and TAO YIN \\ Department of Oncology, Cancer Center, West China Hospital, Sichuan University and \\ Collaborative Innovation Center of Biotherapy, Chengdu, Sichuan 610041, P.R. China
}

Received December 30, 2015; Accepted February 1, 2017

DOI: $10.3892 /$ etm.2017.4557

\begin{abstract}
Transforming growth factor- $\beta$ (TGF- $\beta$ ), a well-known cytokine with pleiotropic biological functions, has an important role in the regulation of cellular proliferation. Rapamycin has specific antagonistic activity on the function of the mammalian target of the rapamycin signaling pathway. The cooperation of TGF- $\beta$ and rapamycin on the proliferation of Michigan Cancer Foundation (MCF)-7 human breast cancer cells is unclear. The present study demonstrated that TGF- $\beta$ had a growth-arresting effect on MCF-7 cancer cells. TGF- $\beta$ stimulation resulted in the upregulation of several cyclin-dependent kinase inhibitors, including $\mathrm{p} 14^{\mathrm{ARF}}, \mathrm{p} 15^{\mathrm{INK} 4 \mathrm{~b}}, \mathrm{p} 16^{\mathrm{INK} 4 \mathrm{a}}$ and $\mathrm{p} 21^{\mathrm{WAF} 1 / \mathrm{CIP} 1}$. The present study also demonstrated that rapamycin enhances the antiproliferative effect of TGF- $\beta$. The combination of rapamycin and TGF- $\beta$ induced apoptosis of MCF-7 tumor cells. These findings advance the current understanding of the biological effects of TGF- $\beta$ and rapamycin.
\end{abstract}

\section{Introduction}

Transforming growth factor- $\beta$ (TGF- $\beta$ ) is a well-known cytokine with pleiotropic biological functions. TGF- $\beta$ has a pivotal role in various physiological processes and pathological conditions, including development, cancer, senescence, fibrosis, wound healing and tissue regeneration (1-3). As an immunosuppressive cytokine, TGF- $\beta$ has a key role in tumor immune evasion (4). The levels of TGF- $\beta$ are often observed to be elevated in the serum of patients with cancer (5). Notably, TGF- $\beta$ also influences the biological characteristics of cancer stem cells. Research has demonstrated that toll-like receptor 4/NANOG-dependent cancer stem cells are defective in the TGF- $\beta$ pathway (6). Perivascular TGF- $\beta$ suppresses

Correspondence to: Dr Tao Yin, Department of Oncology, Cancer Center, West China Hospital, Sichuan University and Collaborative Innovation Center of Biotherapy, 17 People's South Road, Chengdu, Sichuan 610041, P.R. China

E-mail: yintao03073@163.com

Key words: transforming growth factor- $\beta$, rapamycin, breast cancer, proliferation proliferation and promotes invasion and heterogeneity in squamous cell carcinoma stem cells (7). Importantly, release from TGF- $\beta$-mediated inhibition restores anti-tumor immunity (8).

TGF- $\beta$ regulates numerous functions of epithelial cells. TGF- $\beta$ is a well-documented inducer of epithelial-to-mesenchymal transition (EMT) during embryogenesis, cancer progression and fibrosis (9). Both exogenous TGF- $\beta$ protein and TGF- $\beta$ from other sources, such as platelets, are able to induce EMT $(10,11)$. Several lines of evidence indicate that TGF- $\beta$ is able to promote cell proliferation of thyroid epithelial cells (12) and various tumor cells $(13,14)$; however, it also has antiproliferative effects on other cells $(15,16)$. Such conflicting findings suggest that the effects of TGF- $\beta$ are dependent on cell type and context.

The mammalian target of rapamycin (mTOR) signaling pathway has a critical role in regulating basic cellular functions, including cell proliferation, survival, mobility and angiogenesis (17). Rapamycin has specific antagonistic action on the function of mTOR. Rapamycin induces cell cycle arrest in many cells $(18,19)$; however, the combinational effect of rapamycin and TGF- $\beta$ on tumor cells is unclear. In the present study, it was demonstrated that TGF- $\beta$ had a cytostatic effect on Michigan Cancer Foundation (MCF)-7 human breast cancer cells. TGF- $\beta$ induced upregulation of the cyclin-dependent kinase inhibitors (CKIs) p14 ${ }^{\mathrm{ARF}}, \mathrm{p} 15^{\mathrm{INK} 4 \mathrm{~b}}, \mathrm{p} 16^{\mathrm{INK} 4 \mathrm{a}}$ and $\mathrm{p} 21^{\mathrm{WAF} 1 / \mathrm{CIP} 1}$. Notably, it was demonstrated that rapamycin enhanced the antiproliferative effect of TGF- $\beta$.

\section{Materials and methods}

Cell culture and reagents. Human breast cancer cell line MCF-7 was purchased from American Type Culture Collection (Manassas, VA, USA). Tumor cells were cultured and propagated in Dulbecco's modified Eagle medium (Gibco; Thermo Fisher Scientific, Inc., Waltham, MA, USA) supplemented with $10 \%$ fetal bovine serum at $37^{\circ} \mathrm{C}\left(5 \% \mathrm{CO}_{2}\right)$. Rapamycin was obtained from Selleck Chemicals (Houston, TX, USA) and dissolved in dimethyl sulfoxide. Recombinant human TGF- $\beta 1$ was purchased from HumanZyme, Inc. (Chicago, IL, USA) and dissolved in $4 \mathrm{mM}$ hydrochloric acid.

Cell viability assay. A total of $5 \times 10^{4} \mathrm{MCF}-7$ cells were plated on 6-well plastic plates. Cells were treated with 5 and $10 \mathrm{ng} / \mathrm{ml}$ 
TGF- $\beta$, in the presence or absence of $100 \mathrm{nM}$ rapamycin, or an equivalent volume of vehicles. Cell number was counted manually $120 \mathrm{~h}$ after treatment. An MTT assay was performed using 96-well plates in order to determine cell viability. A total of $2.5 \times 10^{3}$ cells per well were seeded in the 96 -well plates. Tumor cells were exposed to $10 \mathrm{ng} / \mathrm{ml}$ TGF- $\beta$ and/or $100 \mathrm{nM}$ rapamycin on the following day. Tumor cell viability was evaluated at $0,24,48,72,96$ and $120 \mathrm{~h}$ after experiment initiation. For the MTT assay, $20 \mu \mathrm{l}$ MTT reagent $(5 \mathrm{mg} / \mathrm{ml})$ was added to each well and the plates were incubated for an additional $4 \mathrm{~h}$ at $37^{\circ} \mathrm{C}$. Subsequently, the formazan precipitates in the cells were dissolved in $150 \mathrm{ml}$ dimethyl sulfoxide after removal of the supernatant. Absorbance was determined at $570 \mathrm{~nm}$ and a growth curve was plotted.

Reverse transcription-quantitative polymerase chain reaction (RT-qPCR). Total RNA was isolated from tumor tissues using an RNA isolation kit (Axygen, Tewksbury, MA, USA). RNA was then treated with DNase to remove genomic DNA and subsequently reverse transcribed (PrimeScript RT reagent kit with gDNA Eraser; Takara Biotechnology Co., Ltd., Dalian, China) according to the manufacturer's instructions. qPCR was performed on a CFX 96 real-time PCR thermocycler (Bio-Rad Laboratories, Inc., Hercules, CA, USA) using specific primers and SYBR Green supermix (Takara Biotechnology Co., Ltd.). RT-qPCR experimental procedures were performed according to the manufacturer's protocol with some changes (SYBR Premix Ex Taq II; Takara Biotechnology Co., Ltd.). The total PCR reaction volume was $25 \mu \mathrm{l}$, which contained $12.5 \mu \mathrm{l}$ supermix, 9.5 $\mu \mathrm{H} \mathrm{H}_{2} \mathrm{O}, 1 \mu \mathrm{l} \mathrm{cDNA}, 1 \mu \mathrm{l}$ forward primers and $1 \mu 1$ reverse primers. PCR conditions were as follows: Initial denaturation for $30 \mathrm{sec}$ at $95^{\circ} \mathrm{C}, 40$ cycles at $95^{\circ} \mathrm{C}$ for $5 \mathrm{sec}$, $60^{\circ} \mathrm{C}$ for $30 \mathrm{sec}, 15 \mathrm{sec}$ at $95^{\circ} \mathrm{C}$ and $5 \mathrm{sec}$ at $65^{\circ} \mathrm{C}$. Primers used for qPCR have previously been described (20). The sequences were as follows: p14ARF, forward 5'-TCCTCAGTA GCATCAGCACGAG-3' and reverse 5'-AGAACATGGTGC GCAGGTTCTTG-3'; p15INK4b, forward 5'-GGGAGGGTA ATGAAGCTGAG-3' and reverse 5'-GGCCGTAAACTTAAC GACACT-3'; p16INK4a, forward 5'-GGGTCCCAGTCTGCA GTTA-3' and reverse 5'-GGAGGGTCACCAAGAACCT-3'; p21 WAF1/CIP1, forward 5'-GCAGACCAGCATGACAGA TTT-3' and reverse 5'-GGATTAGGGCTTCCTCTTGGA-3'; and GAPDH, forward 5'-AGAAGGCTGGGGCTCATTTG-3' and reverse 5'-AGGGGCCATCCACAGTCTTC-3'. Relative gene expression levels were quantified using the $2^{-\Delta \Delta C \mathrm{q}}$ method with GAPDH as reference (21). PCR was repeated in triplicate.

Flow cytometric analysis. A total of $5 \times 10^{4} \mathrm{MCF}-7$ cells were plated on 6-well plastic plates and treated with $10 \mathrm{ng} / \mathrm{ml}$ TGF- $\beta$ and/or $100 \mathrm{nM}$ rapamycin, or an equivalent volume of vehicles. After $72 \mathrm{~h}$, cells were harvested and stained with annexin-V-FITC and propidium iodide (PI). Apoptotic cells were quantified using a FACSCalibur flow cytometer and analyzed using CellQuest software (version 6.0; BD Biosciences, San Jose, CA, USA).

Statistical analysis. Statistical significance was determined using Student's t-tests between two groups, and one-way analysis of variance was used when comparing more than three groups followed by least significant difference and
Student-Newman-Keuls analysis. SPSS version 13.0 software (SPSS Inc., Chicago, IL, USA) was used for statistical analysis. Results were expressed as the mean \pm standard deviation. $\mathrm{P}<0.05$ was considered to indicate a statistically significant difference.

\section{Results}

TGF- $\beta$ exhibits a cytostatic effect on MCF-7 tumor cells. To investigate whether TGF- $\beta$ influences the proliferation of tumor cells, human breast cancer MCF-7 cells were incubated with 5 or $10 \mathrm{ng} / \mathrm{ml}$ concentrations of human TGF- $\beta$. Results demonstrated that TGF- $\beta$ decreased cell numbers in a dose-dependent manner. A dose of $10 \mathrm{ng} / \mathrm{ml}$ TGF- $\beta$ significantly impaired tumor cell proliferation compared with vehicle controls ( $\mathrm{P}<0.05$; Fig. 1A). A $5 \mathrm{ng} / \mathrm{ml}$ dose of TGF- $\beta$ also exhibited a significant cytostatic effect on MCF-7 cell proliferation $(\mathrm{P}<0.05)$, although to a lesser extent when compared with the $10 \mathrm{ng} / \mathrm{ml}$ dose (Fig. 1A). The MTT assay was adapted to assess the viability of tumor cells in the presence of $10 \mathrm{ng} / \mathrm{ml}$ TGF- $\beta$. In the presence of TGF- $\beta$, the viability of $\mathrm{MCF}-7$ cells was significantly reduced compared with the vehicle group from $48 \mathrm{~h}$ onwards $(\mathrm{P}<0.05$; Fig. 1B). It was therefore concluded that TGF- $\beta$ exhibited a cytostatic effect on MCF-7 tumor cells.

TGF- $\beta$ modulates cell cycle regulators. Considering that TGF- $\beta$ had a cytostatic effect on MCF-7 tumor cells, the effect of TGF- $\beta$ on the induction of CKIs was investigated. Following exposure to TGF- $\beta$, the expression of cell-cycle inhibitors $\mathrm{p} 14^{\mathrm{ARF}}, \mathrm{p} 15^{\mathrm{INK} 4 \mathrm{~b}}, \mathrm{p} 16^{\mathrm{INK} 4 \mathrm{a}}$ and $\mathrm{p} 21^{\mathrm{WAF} 1 / \mathrm{CIP} 1}$ was assessed. RT-qPCR analysis demonstrated that TGF- $\beta$ significantly increased the expression levels of $\mathrm{p} 15^{\mathrm{INK} 4 \mathrm{~b}}, \mathrm{p} 16^{\mathrm{INK} 4 \mathrm{a}}$ and $\mathrm{p} 21^{\mathrm{WAF} 1 / \mathrm{CIP} 1}$ in MCF-7 cells compared with vehicle controls $\left(\mathrm{P}<0.05\right.$; Fig. 2); it also increased p14 ${ }^{\mathrm{ARF}}$, though this was not statistically significant. This suggests that TGF- $\beta$ may have a potential regulatory role in CKI expression.

Rapamycin enhances the antiproliferative effect of TGF- $\beta$. The influence of rapamycin, a well-known mTOR inhibitor, on the antiproliferative effect of TGF- $\beta$ was investigated. MCF-7 cells were exposed to $100 \mathrm{nM}$ rapamycin and 5 or $10 \mathrm{ng} / \mathrm{ml}$ TGF- $\beta$. MTT assay demonstrated that rapamycin significantly inhibited MCF-7 cell viability compared with vehicle controls after $48 \mathrm{~h}$ of experiment initiation. Unexpectedly, it was demonstrated that in the presence of both rapamycin and TGF- $\beta$, MCF-7 cells proliferated significantly slower compared with the single treatments of rapamycin or TGF- $\beta$ ( $\mathrm{P}<0.05$; Fig. 3$)$. These results suggest that rapamycin enhances the antiproliferative effect of TGF- $\beta$.

Combination treatment with rapamycin and TGF- $\beta$ induces apoptosis. An investigation was conducted in order to determine whether the combination of rapamycin and TGF- $\beta$ was able to induce apoptosis of MCF-7 tumor cells. MCF-7 cells were treated with $100 \mathrm{nM}$ rapamycin and $10 \mathrm{ng} / \mathrm{ml}$ TGF- $\beta$ for 5 days, and subsequently the cells were stained with annexin-V-FITC and PI. Enumeration of the percentage of viable cells by flow cytometry demonstrated that neither rapamycin nor TGF- $\beta$ alone induced apoptosis; however, a significant decrease in cell viability was observed in the 
A

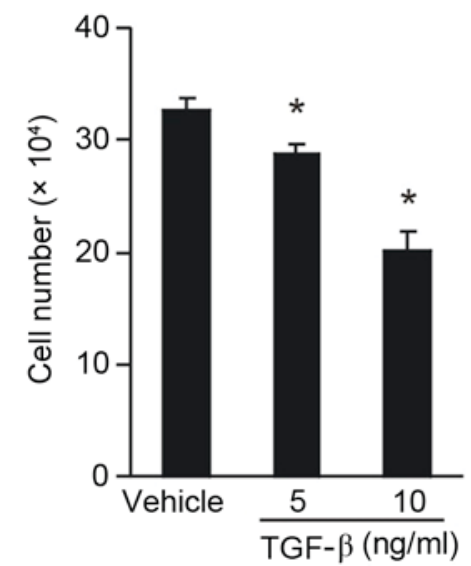

B

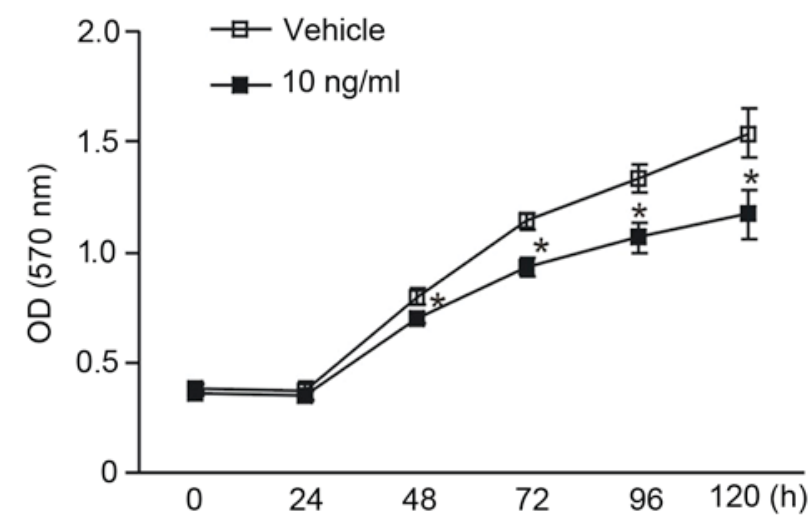

Figure 1. TGF- $\beta$ inhibits the viability of MCF-7 human breast cancer cells. (A) MCF-7 cells were exposed to 5 and $10 \mathrm{ng} / \mathrm{ml}$ TGF- $\beta$. Cell number was counted after $120 \mathrm{~h}$. Data are presented as the mean + standard deviation. (B) Growth rate of MCF-7 cells treated with $10 \mathrm{ng} / \mathrm{ml} \mathrm{TGF}-\beta$ was assessed by MTT assay. TGF- $\beta$ exhibited a viability-arresting effect on MCF-7 tumor cells. Data are presented as the mean \pm standard deviation. "P<0.05 vs. vehicle. TGF- $\beta$, transforming growth factor- $\beta$; MCF-7, Michigan Cancer Foundation-7; OD, optical density.

presence of both rapamycin and TGF- $\beta$ compared with the vehicle control and individual treatments of rapamycin or TGF- $\beta$ ( $\mathrm{P}<0.05$; Fig. 4). These results suggest that the combination of rapamycin and TGF- $\beta$ induces MCF-7 tumor cell apoptosis.

\section{Discussion}

The present study demonstrated that TGF- $\beta$ exhibited cytostatic effects on human breast adenocarcinoma MCF-7 cells, which may be associated with the upregulation of CKIs, including $\mathrm{p} 14^{\mathrm{ARF}}, \mathrm{p} 15^{\mathrm{INK} 4 \mathrm{~b}}, \mathrm{p} 16^{\mathrm{INK} 4 \mathrm{a}}$ and $\mathrm{p} 21^{\mathrm{WAF} 1 / \mathrm{CIP} 1}$. It was also demonstrated that rapamycin enhanced the antiproliferative effect of TGF- $\beta$. In addition, rapamycin and TGF- $\beta$ induced apoptosis of MCF-7 tumor cells.

TGF- $\beta$ is involved in a variety of processes, including proliferation, differentiation, apoptosis, adhesion, EMT, and extracellular matrix deposition, which are essential for tissue homeostasis (1). In the present study, it was demonstrated that recombinant TGF- $\beta$ inhibited the proliferation of MCF-7 cells. This result was consistent with a previous study by Mazars et al (22). Porcine TGF- $\beta 1$ was used in the study by Mazars et al (22), whereas the present study used recombinant human TGF- $\beta$, which was more suitable for the physiological conditions. CKIs have been demonstrated to be causally associated with the inhibitory effect of TGF- $\beta$; in ovarian cancer cells, TGF- $\beta$ decreases cyclin-dependent kinase 2 activity and induces $\mathrm{p} 21^{\mathrm{WAF} / \mathrm{CIP1}}(23)$. Other studies have demonstrated that the effect of TGF- $\beta$ on growth inhibition is mediated by Smad complexes with forkhead box $\mathrm{O}$ factors, which activate $\mathrm{p} 15^{\mathrm{INK} 4 \mathrm{~b}}$ and $\mathrm{p} 21^{\mathrm{CIP1}}(24,25)$. TGF- $\beta$ has also been demonstrated to suppress transcription of the Myc gene; in breast cancer cells that are insensitive to TGF- $\beta$, the defective repression of Myc is frequently observed (26). TGF- $\beta$ inhibits cell proliferation by inhibiting c-Myc expression accompanied by the induction of p15 and p21 expression $(27,28)$. The transcription factor CCAAT-enhancer binding protein $\beta$, essential for the induction of $\mathrm{p} 15^{\mathrm{INK} 4 \mathrm{~b}}$ and the repression of $\mathrm{c}-\mathrm{Myc}$, has been demonstrated to be central to the cytostatic program initiated by TGF- $\beta$ (25).

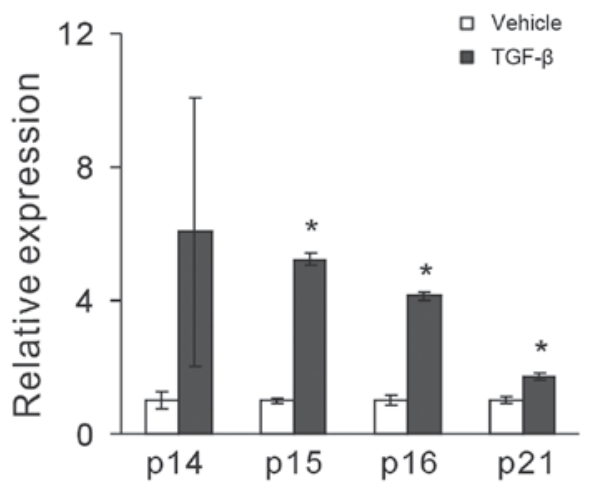

Figure 2 . TGF- $\beta$ upregulates cyclin-dependent kinase inhibitors. MCF-7 cells were treated with $10 \mathrm{ng} / \mathrm{ml}$ TGF- $\beta$. Expression levels of $\mathrm{p} 14^{\mathrm{ARF}}, \mathrm{p} 15^{\mathrm{INK} 4 \mathrm{~b}}$, $\mathrm{p} 16^{\mathrm{INK} 4 \mathrm{a}}$ and $\mathrm{p} 21^{\mathrm{WAF} / \mathrm{CIP1} 1}$ were evaluated using reverse transcription-quantitative polymerase chain reaction. Data are presented as the mean \pm standard deviation. ${ }^{*} \mathrm{P}<0.05$ vs. vehicle. TGF- $\beta$, transforming growth factor- $\beta$; MCF-7, Michigan Cancer Foundation-7.

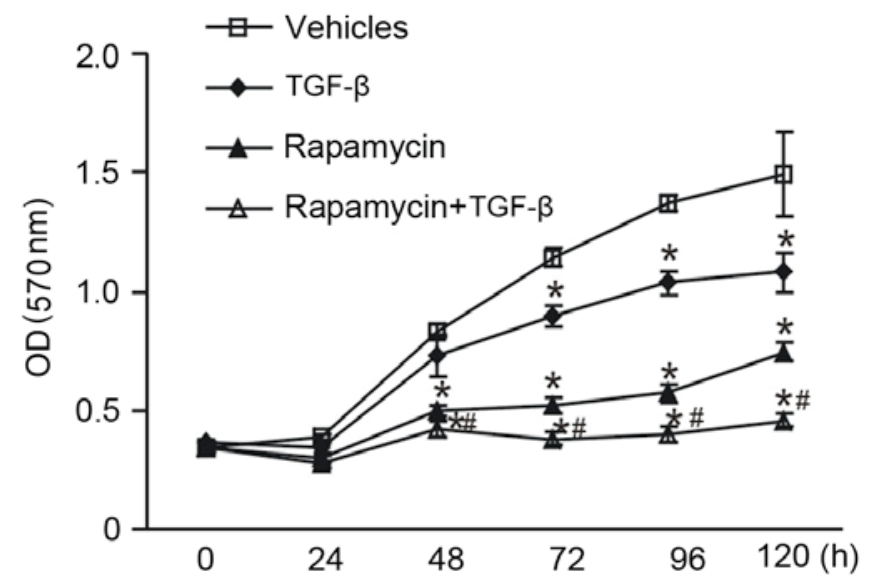

Figure 3. Rapamycin enhances the antiviability effect of TGF- $\beta$. MCF-7 cells were treated with $10 \mathrm{ng} / \mathrm{ml}$ TGF- $\beta$ or/and $100 \mathrm{nM}$ rapamycin. After $0,24,48$, 72,96 and $120 \mathrm{~h}$, the viability of tumor cells was evaluated by MTT assay. Data are presented as the mean \pm standard deviation. ${ }^{*} \mathrm{P}<0.05$ vs. vehicles and ${ }^{\#} \mathrm{P}<0.05$ vs. TGF- $\beta$ or rapamycin. TGF- $\beta$, transforming growth factor $\beta$; MCF-7, Michigan Cancer Foundation-7; OD, optical density. 
A

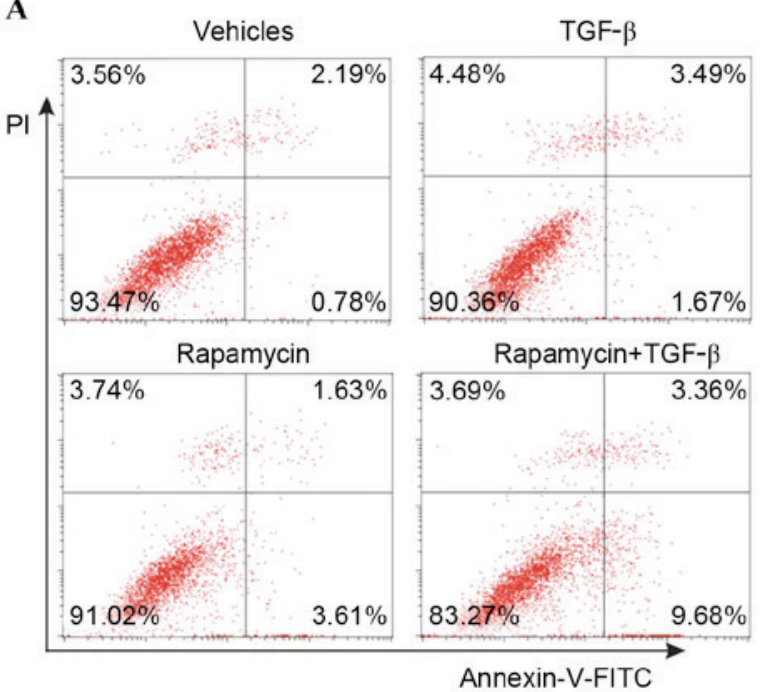

B

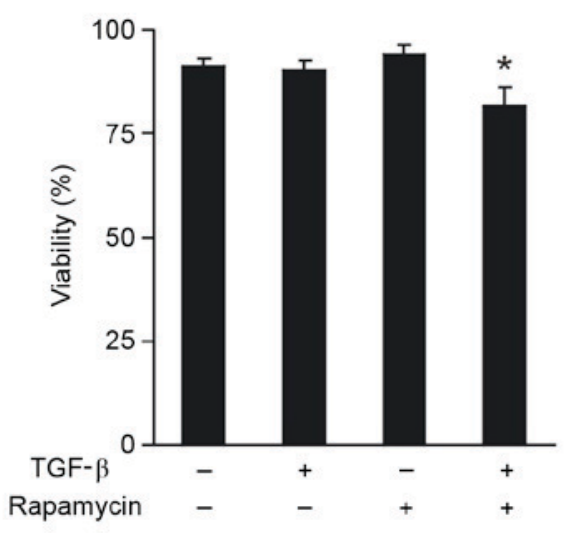

Figure 4. Combination of TGF- $\beta$ and rapamycin induces apoptosis of MCF-7 tumor cells. MCF-7 tumor cells were treated with 10 ng/ml TGF- $\beta$ or/and 100 nM rapamycin. (A) After $72 \mathrm{~h}, \mathrm{MCF}-7$ cells were stained with annexin-V-FITC and PI. (B) The percentage of viable cells was enumerated using flow cytometry. Data are present as the mean + standard deviation. * $\mathrm{P}<0.05$ vs. vehicles and individual treatment. TGF- $\beta$, transforming growth factor- $\beta$; MCF-7, Michigan Cancer Foundation-7; PI, propidium iodide; FITC, fluorescein isothiocyanate.

The results of the present study demonstrated that, in MCF-7 tumor cells, TGF- $\beta$ induced the expression of $\mathrm{p} 14^{\mathrm{ARF}}, \mathrm{p} 15^{\mathrm{INK} 4 \mathrm{~b}}$, $\mathrm{p} 16^{\mathrm{INK} 4 \mathrm{a}}$ and $\mathrm{p} 21^{\mathrm{WAF} 1 / \mathrm{CIP} 1}$, which may be associated with the growth-arresting effects of TGF- $\beta$. Notably, it has been reported that the response of fibroblasts and epithelial cells to TGF- $\beta$ differs, with TGF- $\beta$ increasing the proliferation of fibroblasts and inducing cell cycle arrest of epithelial cells (29). TGF- $\beta$ also functions to maintain the pool of quiescent hematopoietic stem cells (30). Notably, TGF- $\beta$ transcriptionally activates p21, which stabilizes nuclear factor (erythroid-derived 2)-like 2, enhancing glutathione metabolism and diminishing the effectiveness of anticancer therapeutics (7).

mTOR complex 1 is a critical regulator of Gap 1 (G1) cell cycle progression and rapamycin is able to induce $\mathrm{G} 1$ cell cycle arrest in MDA-MB-231 breast cancer cells (19). The present study demonstrated that $100 \mathrm{nM}$ rapamycin alone was able to inhibit the proliferation of MCF-7 cells. This effect may be associated with the relatively low levels of phospholipase D activity in MCF-7 cells (31). The present study demonstrated, for the first time, that rapamycin enhances the growth-arresting effect of TGF- $\beta$ on MCF-7 tumor cells. Therefore, it is now evident that low doses of rapamycin are sufficient for activating TGF- $\beta$ signaling (18). Rapamycin-induced G1 cell cycle arrest employs both TGF- $\beta$ and retinoblastoma pathways (19), which may partly explain the combinational action of TGF- $\beta$ and rapamycin. Neither $100 \mathrm{nM}$ rapamycin nor $10 \mathrm{ng} / \mathrm{ml}$ TGF- $\beta$ alone induced apoptosis in MCF-7 cells; however, the combination of both rapamycin and TGF- $\beta$ resulted in significant apoptosis. The induction of apoptosis by TGF- $\beta$ has been demonstrated to be cell type-dependent. TGF- $\beta$ induces apoptosis in thyrocytes, and p2 $7^{\mathrm{kip} 1}$ reduction is a key event in this process (16). Further investigation is required to clarify the mechanism of the combinational effect of TGF- $\beta$ and rapamycin on apoptosis.

In conclusion, the present study demonstrated that rapamycin enhances the antiproliferative effect of TGF- $\beta$ on human MCF-7 tumor cells. These findings advance the current understanding of the biological effects of TGF- $\beta$ and rapamycin.

\section{Acknowledgements}

This research was supported by the National Natural Science Foundation of China (grant no. 81501609) and the China Postdoctoral Science Foundation (grant no. 2015M582553).

\section{References}

1. Massagué J: TGFbeta in cancer. Cell 134: 215-230, 2008

2. Cipriano R, Kan CE, Graham J, Danielpour D, Stampfer M and Jackson MW: TGF- $\beta$ signaling engages an ATM-CHK2-p53-independent RAS-induced senescence and prevents malignant transformation in human mammary epithelial cells. Proc Natl Acad Sci USA 108: 8668-8673, 2011.

3. Schiller M, Javelaud D and Mauviel A: TGF-beta-induced SMAD signaling and gene regulation: Consequences for extracellular matrix remodeling and wound healing. J Dermatol Sci 35: 83-92, 2004.

4. Flavell RA, Sanjabi S, Wrzesinski SH and Licona-Limón P: The polarization of immune cells in the tumour environment by TGFbeta. Nat Rev Immunol 10: 554-567, 2010.

5. Lee JC,LeeKM,Kim DW and Heo DS:Elevated TGF-beta1 secretion and down-modulation of NKG2D underlies impaired NK cytotoxicity in cancer patients. J Immunol 172: 7335-7340, 2004.

6. Chen CL, Tsukamoto H, Liu JC, Kashiwabara C, Feldman D, Sher L, Dooley S, French SW, Mishra L, Petrovic L, et al: Reciprocal regulation by TLR4 and TGF- $\beta$ in tumor-initiating stem-like cells. J Clin Invest 123: 2832-2849, 2013.

7. Oshimori N, Oristian D and Fuchs E: TGF- $\beta$ promotes heterogeneity and drug resistance in squamous cell carcinoma. Cell 160: 963-976, 2015.

8. Gorelik L and Flavell RA: Immune-mediated eradication of tumors through the blockade of transforming growth factor-beta signaling in T cells. Nat Med 7: 1118-1122, 2001.

9. Xu J, Lamouille S and Derynck R: TGF-beta-induced epithelial to mesenchymal transition. Cell Res 19: 156-172, 2009.

10. Shiota M, Zardan A, Takeuchi A, Kumano M, Beraldi E, Naito S, Zoubeidi A and Gleave ME: Clusterin Mediates TGF- $\beta$-induced epithelial-mesenchymal transition and metastasis via twist1 in prostate cancer cells. Cancer Res 72: 5261-5272, 2012. 
11. Labelle M, Begum S and Hynes RO: Direct signaling between platelets and cancer cells induces an epithelial-mesenchymal-like transition and promotes metastasis. Cancer Cell 20: 576-590, 2011.

12. Fang Y, Yu S and Braley-Mullen H: TGF- $\beta$ promotes proliferation of thyroid epithelial cells in IFN- $\gamma(-/-)$ mice by down-regulation of p21 and p27 via AKT pathway. Am J Pathol 180: 650-660, 2012.

13. Lu SL, Reh D, Li AG, Woods J, Corless CL, Kulesz-Martin M and Wang XJ: Overexpression of transforming growth factor betal in head and neck epithelia results in inflammation, angiogenesis, and epithelial hyperproliferation. Cancer Res 64: 4405-4410, 2004.

14. Tang B, Vu M, Booker T, Santner SJ, Miller FR, Anver MR and Wakefield LM: TGF-beta switches from tumor suppressor to prometastatic factor in a model of breast cancer progression. J Clin Invest 112: 1116-1124, 2003.

15. Lyons RM and Moses HL: Transforming growth factors and the regulation of cell proliferation. Eur J Biochem 187: 467-473, 1990.

16. Bravo SB, Pampin S, Cameselle-Teijeiro J, Carneiro C, Domínguez F, Barreiro F and Alvarez CV: TGF-beta induced apoptosis in human thyrocytes is mediated by $\mathrm{p} 27 \mathrm{kip} 1$ reduction and is overridden in neoplastic thyrocytes by NF-kappaB activation Oncogene 22: 7819-7830, 2003.

17. Chan S: Targeting the mammalian target of rapamycin (mTOR): A new approach to treating cancer. Br J Cancer 91: 1420-1424, 2004.

18. Yellen P, Saqcena M, Salloum D, Feng J, Preda A, Xu L, Rodrik-Outmezguine V and Foster DA: High-dose rapamycin induces apoptosis in human cancer cells by dissociating mTOR complex 1 and suppressing phosphorylation of 4E-BP1. Cell Cycle 10: 3948-3956, 2011.

19. Chatterjee A, Mukhopadhyay S, Tung K, Patel D and Foster DA: Rapamycin-induced G1 cell cycle arrest employs both TGF- $\beta$ and $\mathrm{Rb}$ pathways. Cancer Lett 360: 134-140, 2015.

20. Wan G, Mathur R, Hu X, Liu Y, Zhang X, Peng G and Lu X Long non-coding RNA ANRIL (CDKN2B-AS) is induced by the ATM-E2F1 signaling pathway. Cell Signal 25: 1086-1095, 2013.

21. Livak KJ and Schmittgen TD: Analysis of relative gene expression data using real-time quantitative PCR and the 2(-Delta Delta C(T)) Method. Methods 25: 402-408, 2001
22. Mazars P, Barboule N, Baldin V, Vidal S, Ducommun B and Valette A: Effects of TGF-beta 1 (transforming growth factor-beta 1) on the cell cycle regulation of human breast adenocarcinoma (MCF-7) cells. FEBS Lett 362: 295-300, 1995.

23. Elbendary A, Berchuck A, Davis P, Havrilesky L, Bast RC Jr, Iglehart JD and Marks JR: Transforming growth factor beta 1 can induce CIP1/WAF1 expression independent of the p53 pathway in ovarian cancer cells. Cell Growth Diff 5: 1301-1307, 1994.

24. Seoane J, Le HV, Shen L, Anderson SA and Massagué J: Integration of Smad and forkhead pathways in the control of neuroepithelial and glioblastoma cell proliferation. Cell 117: 211-223, 2004.

25. Gomis RR, Alarcón C, He W, Wang Q, Seoane J, Lash A and Massagué J: A FoxO-Smad synexpression group in human keratinocytes. Proc Natl Acad Sci USA 103: 12747-12752, 2006.

26. Chen CR, Kang Y and Massagué J: Defective repression of c-myc in breast cancer cells: A loss at the core of the transforming growth factor beta growth arrest program. Proc Natl Acad Sci USA 98: 992-999, 2001.

27. Datto MB, Li Y, Panus JF, Howe DJ, Xiong Y and Wang XF: Transforming growth factor beta induces the cyclin-dependent kinase inhibitor p21 through a p53-independent mechanism. Proc Natl Acad Sci USA 92: 5545-5549, 1995.

28. Li JM, Nichols MA, Chandrasekharan S, Xiong Y and Wang XF: Transforming growth factor beta activates the promoter of cyclin-dependent kinase inhibitor p15INK4B through an Sp1 consensus site. J Biol Chem 270: 26750-26753, 1995.

29. Hosobuchi M and Stampfer MR: Effects of transforming growth factor beta on growth of human mammary epithelial cells in culture. In Vitro Cell Dev Biol 25: 705-713, 1989.

30. Mo AD, Joseph H and Nolta JA: Molecular mechanism of transforming growth factor beta-mediated cell-cycle modulation in primary human CD34(+) progenitors. Blood 99: 499-506, 2002.

31. Chen Y, Zheng Y and Foster DA: Phospholipase D confers rapamycin resistance in human breast cancer cells. Oncogene 22: 3937-3942, 2003. 